\title{
Spatiotemporal variation of methane and other trace hydrocarbon concentrations in the Valley of Mexico
}

\author{
Felisa A. Smith ${ }^{\mathrm{a}, *}$, Scott Elliott ${ }^{\mathrm{b}}$, Donald R. Blake ${ }^{\mathrm{c}}$, F. Sherwood Rowland ${ }^{\mathrm{c}}$ \\ a Department of Biology, University of New Mexico, Albuquerque, NM 87131, USA \\ ${ }^{\mathrm{b}}$ Atmospheric and Climate Sciences Group, Division of Earth and Environmental Sciences, \\ Los Alamos National Laboratory, Los Alamos, NM 87545, USA \\ ${ }^{\mathrm{c}}$ Department of Chemistry, Rowland Hall, University of California, Irvine, CA 92697, USA
}

\begin{abstract}
Mexico City is the world's largest and most polluted urban center. We examine the distribution of methane and other hydrocarbons within the Valley of Mexico, using it as a model for the role developing megacities will play in the next century of geochemical cycling. Seventy-five whole air samples were analyzed with multivariate statistical techniques, including factor analysis using principal components. Methane concentrations are highly variable in space and time, due to air circulations and source distribution. Landfills and open sewage canals are major inputs. Emissions into and out from the valley are modeled to be $\sim 515 \mathrm{t}$ per day. Per capita emission is $0.01 \mathrm{t}$ per annum per person, consistent with the global average for human related anaerobic generation. Natural gas leaks are small, and likely to be higher in other developing megacities; Mexican natural gas use has been discouraged out of earthquake safety concerns. In contrast, liquefied petroleum gas loss constitutes the major emission of propane and butane estimated at a leak rate of 5-10\%. Kyoto and other environmental conventions have ignored methane as a greenhouse gas. Our analysis underscores the need to consider methane and other hydrocarbons, and the urbanization process, in future emission protocols.
\end{abstract}

(C) 2002 Elsevier Science Ltd. All rights reserved.

Keywords: Mexico City; Climate forcing; Factor analysis; Source receptor analysis; Megacities

\section{Introduction}

In 1989, the United Nations (UN, 1989) estimated that almost half the global population would be living in urban areas by the year 2000 , with continued aggregation leading to an increasing number of megacities. In many ways, the Valley of Mexico can be considered an archetype of the evolution of megacities in underdeveloped countries. Until fairly recently, urban planning in Mexico City has been largely nonexistent and/or ignored, and consequently growth has been rampant, chaotic and unstructured (WHO/UNEP, 1992; Nord, 1996; Pick and Butler, 1997). Approximately $40 \%$ of citizens live in 'informal settlements', often without water, sewage or regulated utilities; additionally some $>30,000$ industries are located within the basin (UNCHS, 1986; WHO/UNEP, 1992; Chen and Heligman, 1994). Unregulated expansion has led to widespread pollution problems and Mexico City now has what may be the worst air quality in the world (WHO/UNEP, 1992, 1994). As

\footnotetext{
* Corresponding author. Tel.: +1-505-277-6725; fax: +1-505-277-0304.

E-mail addresses: fasmith@unm.edu (F.A. Smith),

selliott@kokopelli.lanl.gov (S. Elliott).
}

developing areas become concerned with the aesthetic, health and environmental costs of air pollution, they have turned to cleaner burning energy sources such as natural and liquefied petroleum gas. In the Valley of Mexico, for example, power generation plants were switched from fuel oil to natural gas in 1991 because of pollution concerns (WHO/UNEP, 1992). Although natural gas releases much less carbon dioxide, particulate and sulfur dioxide than other fuels, methane is approximately 25-30 times more potent than carbon dioxide as a greenhouse species (Lelieveld and Crutzen, 1992; Lelieveld et al., 1993, 1998; WHO/UNEP, 1992). Leakage from gas infrastructures could thus offset some of the benefit of fuel substitution.

The extreme air pollution problem in metropolitan Mexico City has attracted international research attention, but the emphasis has been on smog chemistry and the urban aerosol (Aldape et al., 1991, 1993; Miranda et al., 1994; MARI, 1994). In Spring 1993, the Rowland/Blake atmospheric chemistry group conducted whole air sampling of a wide spectrum of hydrocarbons, across portions of central Mexico. The species distributions have already been analyzed for their relevance to local oxidant generation (e.g. Blake and Rowland, 1995; Elliott et al., 1997). Here, we 
utilize the data to examine spatial and temporal distributions of methane and other light hydrocarbons within the Valley of Mexico. Multivariate statistical analysis is applied to methane concentrations as well as those of several other light alkanes, and unsaturated double bonded species. Our primary aims are to investigate hydrocarbon source distributions in the Mexico City basin, and to interpret the results in the context of currently emerging megacities. We identify major methane emission types, and derive integrated leak rates for $\mathrm{C}_{3}$ and $\mathrm{C}_{4}$ compounds from the liquefied petroleum gas infrastructure. Mexican governmental agencies have discouraged reliance on natural gas as an energy source in residential areas because pipelines would be subject to earthquake damage (Villarreal et al., 1996). Developing megacities in tectonically stable zones may well develop larger and leakier distribution systems as pollution concerns drive a shift from coal to petroleum gas fuels.

In addition to using multivariate techniques to investigate spatiotemporal variation of methane and other selected hydrocarbon concentrations, we use factor analysis and mass conservation principles to partition chemical compositions into potential sources. Results are compared with geopolitical information on industries, landfills and other potential hydrocarbon emitters. The total flux of methane through the basin is estimated both from 'bottom up' and 'top down' perspectives. Surface level emissions are computed based on accumulation under the nocturnal inversion; outflow is estimated based on burden and air mass turnover. The urban scale production figures are population normalized and compared with global averages. Coupled with government consumption figures, infrastructure leak rates are determined for LPG. Our results are interpreted in the context of historical patterns of urbanization within the central Mexican highlands. We view the flux calculation section as extending a local analysis of atmospheric organic composition into the global policy arena.

\section{Methods}

\subsection{Study area}

The urban area of Mexico City (latitude $19.26 \mathrm{~N}$, longitude $99.07 \mathrm{~W})$ is located in a high elevation basin $(\sim 2240 \mathrm{~m})$, surrounded by mountainous terrain averaging $3500 \mathrm{~m}$. Several nearby volcanic peaks exceed $5000 \mathrm{~m}$ in elevation. The metropolitan area covers some $2500 \mathrm{~km}^{2}$ and is inhabited by close to 20 million people. Population densities range from 500 to 7000 persons $/ \mathrm{km}^{2}$ (WHO/UNEP, 1992, 1994; Pick and Butler, 1997). There are more than 30,000 industries located within the basin, and $233 \%$ of Mexico's GDP is produced there (WHO/UNEP, 1992, 1994). The ancient city of Teotihuacan, located some $60 \mathrm{~km} \mathrm{NE}$ of the outskirts of Mexico City, was used as a baseline for air sampling. Methane levels there were comparable to baseline estimates at other rural locations around the globe (Blake et al., 1984; Houghton et al., 1992, 1996).

\subsection{Air sampling}

Hydrocarbon measurements were obtained through whole air sampling over a 1 week period in March 1993. Samples were relatively well dispersed across the Mexico City metropolitan area (Fig. 1), and were taken at various times from 06:00 to 21:00 h at ground level. Throughout the collection period, atmospheric conditions were mild, with low velocity winds of less than $10-20 \mathrm{~km} / \mathrm{h}$ predominating. A total of 75 canisters were filled, including three at Teotihuacan. The air within them was analyzed by cryogenic separation of the components condensable at liquid nitrogen temperature, followed by multiple-aliquot gas chromatography. Volatile halocarbons were detected by electron capture and hydrocarbons by flame ionization (Blake et al., 1992). More than 70 separate species were identified and quantitatively measured. Further methodological details are presented in Blake et al. (1992, 1996a,b,c) and Blake and Rowland (1995).

\subsection{Data analysis and source receptor modeling}

Data were analyzed using a variety of multivariate procedures from the SPSS statistical package and advanced modules (Norusis, 1986). Because the analysis of trace gas concentration by time phase occasionally violated the assumption of homogeneity of variance, nonparameteric methods were used to confirm important results. Factor reduction by principal components analysis was employed to help identify the potential sources of methane and other trace hydrocarbons (Henry and Hidy, 1979, 1981; Hopke, 1981, 1985; Hopke et al., 1983). Factor analysis identifies a relatively small number of factors that can be used to represent the relationships among sets of correlated variables; this helps distinguish the underlying constructs. A correlation matrix is computed and diagonalization yields eigenvalues. These are analyzed using principal components to extract the most parsimonious number of factors (components) that explain the interrelationships among the variables. We have used the normal convention of restricting the analysis to factors yielding eigenvalues $>1.0$; examination of factor scree plots corroborated the appropriateness of the cutoff. A VARIMAX rotation was performed to ensure components were orthogonal (i.e. uncorrelated with each other). Emission profiles were used to help interpret the factor loadings.

We also applied conservation arguments to distinguish between various anthropogenic sources of methane. Our method resembles the EPA sanctioned chemical mass balance approach (e.g. Watson, 1983; Hopke, 1985), but is conducted at the heuristic level. Direct information on relative source strengths can be obtained by conducting multiple regressions after principal component analysis. We feel that the uncertainties in our catalog of emission fingerprints are too large to warrant a formal source receptor calculation. 


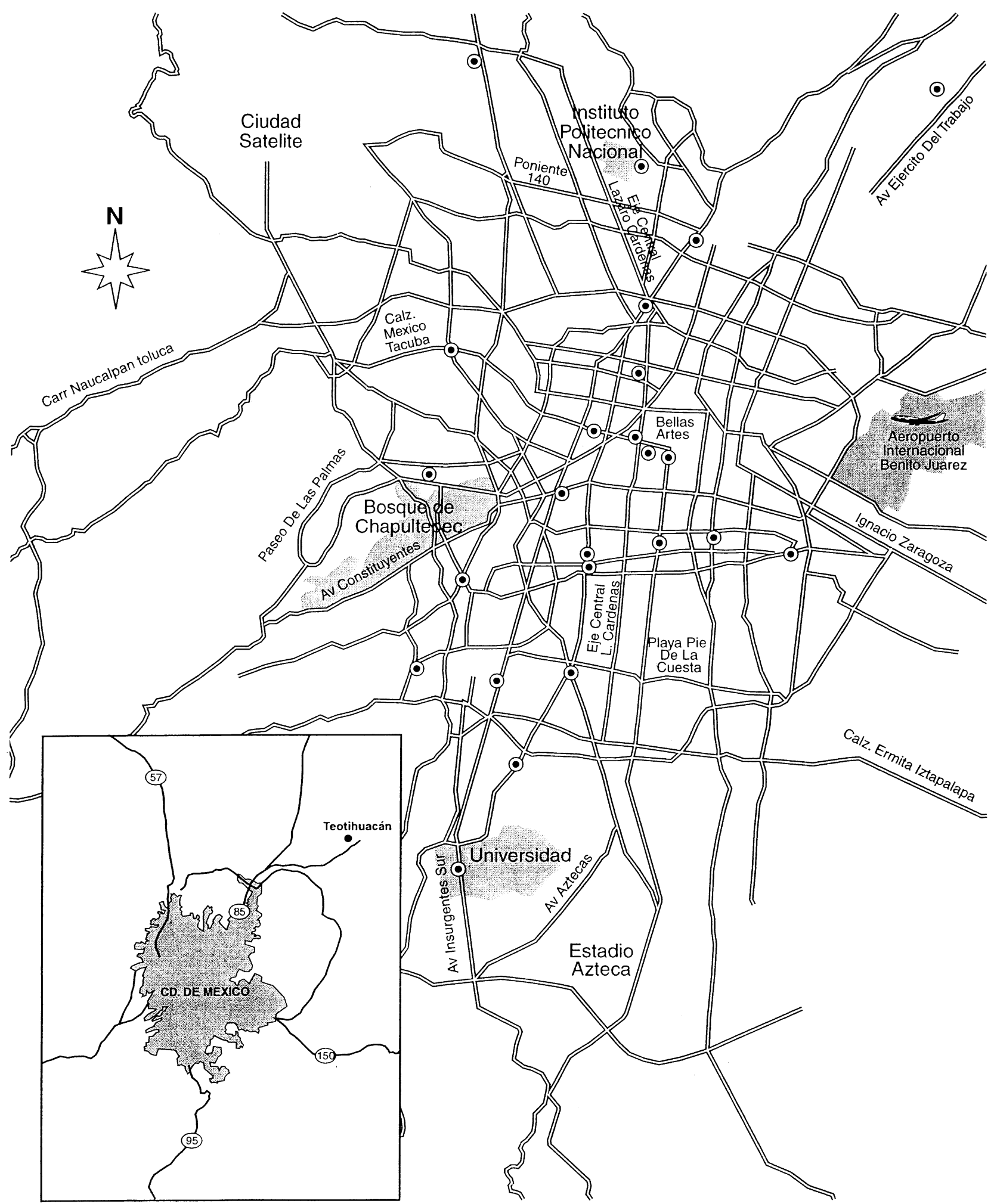

Fig. 1. Map of Mexico City and sampling localities. The urban area of Mexico City is located in a high elevation basin with several of the surrounding mountains exceeding $5000 \mathrm{~m}$. The metropolitan area covers some $2500 \mathrm{~km}^{2}$ and is occupied by $\sim 20$ million people. The ancient city of Teotihuacan, located some $60 \mathrm{~km} \mathrm{NE}$ of the outskirts of Mexico City, was used as a baseline for comparisons. Levels there were comparable to baseline estimates at other locations around the globe (Blake et al., 1984; Houghton et al., 1996). 
Further, the concentrations for key signature molecules were highly variable, making such estimates unreliable.

\section{Results}

\subsection{Statistical analyses-methane}

Methane concentrations in the Valley of Mexico have a predictable diurnal pattern, reflecting the underlying meteorology and air circulation patterns (Table 1). We binned methane and other alkane measurements into $3 \mathrm{~h}$ intervals representing fairly homogeneous atmospheric conditions. Most of the variance in methane could be explained by time phase (one-way analysis of variance, $P<0.001$, d.f. $=71$ ); range tests indicated that concentrations between 03:00 and 12:00 $\mathrm{h}$ were elevated relative to those from 12:00 to 21:00 $\mathrm{h}$ (Scheffle, LSD and Duncan test, $P<0.05$; Fig. 2, Table 1). Because both the Bartlett Box and Cochrans $\mathrm{C}$ tests suggested that significant heterogeneity of variance existed, the analysis was rerun using a nonparametric Kruskal-Wallis one-way ANOVA. Results were also highly significant $(P<0.001)$. The Spearman correlation coefficient between methane concentration and time phase was -0.9429 $(P<0.005$, d.f. $=71)$. When used as a covariate, temperature did not independently influence our results (ANCOVA, $P>0.05)$. Higher concentrations in the morning represent build-up of methane under the nocturnal inversion layer (Elliott et al., 1997); after the layer lifts, vertical mixing resumes and levels approach background (e.g. Table 1, Fig. 2). Heterogeneity in methane concentrations has been reported by other researchers (e.g. Riveros et al., 1995).

We also found a highly significant difference in values from within the metropolitan area and those from a nearby rural site (the pyramids at Teotihuacan), even when data were controlled for time phase (e.g. one-way ANOVA on data from 12:00 to 15:00h, $P<0.02$, d.f. $=20$; Tables 1 and 2). The average methane concentration between 12:00 and 15:00 $\mathrm{h}$ for the urban area was $2.01 \mathrm{ppm}( \pm 0.1478, N=18)$ versus $1.78( \pm 0.01, N=3)$ for Teotihuacan, suggesting an

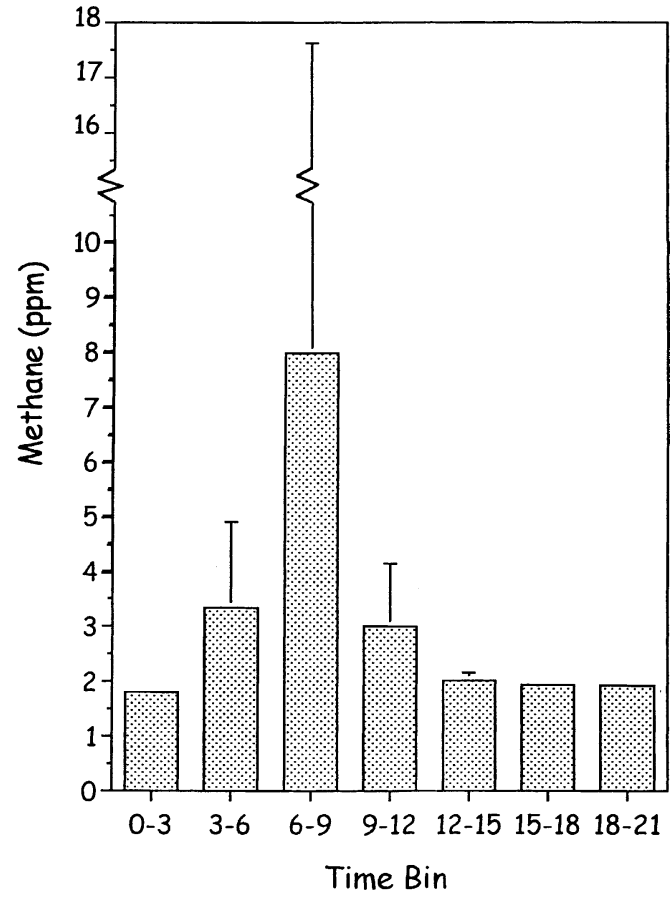

Fig. 2. Variation in methane concentrations (ppm) averaged in $3 \mathrm{~h}$ bins. Bars indicate one standard deviation; if not shown deviations were less than the thickness of the bar. Values are significantly higher during the morning time periods (03:00-12:00 h) before the nocturnal inversion layer disperses. Samples from the same sites sampled both in the morning and late-afternoon differed; atmospheric mixing results in concentrations equivalent to background levels by mid-afternoon.

urban excess of $0.23 \mathrm{ppm}$. The urban value is consistent with measurements by Riveros et al. (1995); that for Teotihuacan is slightly higher than the global average of 1.72 reported by the Houghton et al. $(1992,1996)$ when spatial and temporal differences are taken into account (e.g. Cicerone and Oremland, 1988; Dlugokencky et al., 1994; Lelieveld et al., 1998). The urban excess calculated with the well mixed afternoon mean is comparable to other urban areas (Blake et al., 1984), although these earlier studies did not take time or transport into account. Had the excess been estimated from the morn-

Table 1

Temporal variation and urban excess of several important trace hydrocarbons during the week long sampling campaign

\begin{tabular}{|c|c|c|c|c|c|c|c|c|c|c|}
\hline \multirow[t]{2}{*}{ Time period $(\mathrm{h})$} & \multirow[t]{2}{*}{$N$} & \multicolumn{2}{|c|}{ Methane (ppm) } & \multirow[t]{2}{*}{ Excess $^{\mathrm{a}}$} & \multicolumn{2}{|c|}{ Ethane (ppb) } & \multirow[t]{2}{*}{ Excess } & \multicolumn{2}{|c|}{ Propane (ppb) } & \multirow[t]{2}{*}{ Excess } \\
\hline & & Mean & $\sigma$ & & Mean & $\sigma$ & & Mean & $\sigma$ & \\
\hline $00: 00-03: 00$ & 1 & 1.800 & - & 0.02 & 4.708 & - & 3.227 & 35.480 & - & 31.499 \\
\hline 03:00-06:00 & 8 & 3.336 & 1.555 & 1.553 & 13.105 & 3.856 & 11.624 & 135.198 & 48.589 & 131.217 \\
\hline 06:00-09:00 & 9 & 7.971 & 9.650 & 6.188 & 15.242 & 6.903 & 13.761 & 208.831 & 122.590 & 204.850 \\
\hline 09:00-12:00 & 10 & 2.999 & 1.146 & 1.216 & 15.674 & 5.508 & 14.193 & 115.541 & 64.983 & 111.560 \\
\hline $12: 00-15: 00$ & 17 & 2.015 & 0.143 & 0.232 & 8.991 & 5.076 & 7.510 & 42.307 & 25.097 & 38.326 \\
\hline $15: 00-18: 00$ & 18 & 1.942 & 0.104 & 0.159 & 6.424 & 4.323 & 4.923 & 25.288 & 9.617 & 21.307 \\
\hline $18: 00-21: 00$ & 9 & 1.934 & 0.046 & 0.151 & 10.335 & 2.409 & 8.854 & 44.844 & 12.747 & 40.863 \\
\hline
\end{tabular}

a "Excess" is the difference in concentrations between the Mexico City samples and those measured $60 \mathrm{~km}$ away at the pyramids at Teotihuacan (Fig. 1). Levels of all trace gases at Teotihuacan were consistent with "normal" background levels (see text); the rural site is sufficiently distant from Mexico City to have negligible impact from urban inputs. 
Table 2

Average hydrocarbon concentrations from Mexico City and Teotihuacan

\begin{tabular}{|c|c|c|c|c|c|c|}
\hline \multirow[t]{3}{*}{ Hydrocarbon } & \multicolumn{4}{|l|}{ Urban } & \multirow{2}{*}{\multicolumn{2}{|c|}{$\begin{array}{l}\text { Rural } \\
\text { Afternoon }(12: 00-13: 00 \mathrm{~h}), N=3\end{array}$}} \\
\hline & \multicolumn{2}{|c|}{ Morning (03:00-12:00 h), $N=26$} & \multicolumn{2}{|c|}{ Afternoon (12:00-21:00h), $N=34$} & & \\
\hline & Mean (ppt) & $\sigma$ & Mean (ppt) & $\sigma$ & Mean (ppt) & $\sigma$ \\
\hline 1,3-Butadiene & 931.1 & 521.4 & 958.4 & 1494.6 & 0 & 0 \\
\hline 1-Butene & 2648.6 & 1420.9 & 1419.9 & 1463.6 & 13.3 & 16.7 \\
\hline 1-Hexane & 562.9 & 239.5 & 562.1 & 541.4 & 61.3 & 106.2 \\
\hline 3-Me-pentane & 5850.5 & 3576.4 & 3976.0 & 3697.5 & 121.3 & 28.9 \\
\hline 2-Me-pentane & 9227.2 & 5307.4 & 7596.9 & 5663.3 & 366.7 & 135.9 \\
\hline 1-Pentene & 659.5 & 364.3 & 681.8 & 918.9 & 10.7 & 18.5 \\
\hline Benzene & 5505.8 & 3555.9 & 4711.5 & 4299.9 & 197.3 & 122.7 \\
\hline Toluene & 22043.4 & 14065.8 & 14736.8 & 11898.1 & 366.7 & 6.1 \\
\hline cis-2-Butene & 1759.1 & 1108.5 & 973.4 & 962.4 & 6.7 & 11.5 \\
\hline Cyclopentane & 1215.1 & 680.9 & 1037.9 & 803.4 & 41.3 & 2.3 \\
\hline Ethane & 14164.1 & 4621.8 & 8912.5 & 4668.7 & 1481.3 & 40.35 \\
\hline Ethane & 32433.1 & 19843.1 & 28535.9 & 29993.0 & 758.7 & 204.8 \\
\hline Ethyne & 44137.7 & 28357.4 & 38154.6 & 34653.2 & 1221.3 & 143.2 \\
\hline$i$-Butane & 31387.9 & 18074.6 & 9449.3 & 4671.8 & 769.3 & 92.7 \\
\hline$i$-Butene & 2842.8 & 1454.1 & 2482.4 & 3177.6 & 112.0 & 118.5 \\
\hline$i$-Pentane & 24709.7 & 14055.9 & 19472.7 & 14732.7 & 474.7 & 90.0 \\
\hline Isoprene & 247.2 & 188.9 & 300.0 & 371.0 & 9.3 & 16.2 \\
\hline Methane & 4821307.7 & 6035865.4 & 1982352.9 & 115328.5 & 1783000.0 & 10440.3 \\
\hline Methylcyclopentane & 1027.9 & 592.7 & 883.3 & 989.1 & 0 & 0 \\
\hline$n$-Butane & 67660.3 & 38570.8 & 21848.8 & 10671.6 & 1580.0 & 188.0 \\
\hline$n$-Hexane & 8388.8 & 4771.9 & 6044.2 & 4780.4 & 117.3 & 4.6 \\
\hline$n$-Heptane & 2818.6 & 2100.3 & 2068.2 & 1988.7 & 104.0 & 8.0 \\
\hline$n$-Pentane & 17371.7 & 10244.0 & 14676.9 & 11696.1 & 382.7 & 90.7 \\
\hline Propane & 147201.8 & 89431.2 & 39315.3 & 20282.9 & 3981.3 & 299.5 \\
\hline Propene & 8170.3 & 4024.9 & 6617.5 & 8276.1 & 101.3 & 42.4 \\
\hline Propyne & 655.2 & 482.5 & 598.3 & 755.5 & 0 & 0 \\
\hline trans-2-Butene & 1847.4 & 1348.4 & 932.5 & 1100.0 & 0 & 0 \\
\hline
\end{tabular}

ing values, for example, we would have concluded that it was over an order of magnitude greater (e.g. $6.19 \mathrm{ppm}$; Table 1).

Our analysis also found significant heterogeneity of variance among time phases, with higher values in the morning hours (03:00-12:00 h), and very little variation in concentration in the afternoon samples (e.g. $>12: 00 \mathrm{~h}$ ). The discrepancy probably reflects the higher degree of vertical and horizontal mixing in the mid- to late-afternoon. The results also suggest, however, that at least some methane emissions are derived from point sources, since many morning values were only slightly elevated from background while others were substantially higher (Fig. 2; see also Riveros et al., 1995). Evidence for industrial point source emissions comes from comparison of weekday and weekend values. Although the diurnal pattern in methane concentrations and variance is evident when data are partitioned by day of the week, the morning values are considerably lower on Sundays (Table 3). Many businesses are either closed entirely during the weekend, or close by $14: 00 \mathrm{~h}$ on Saturday (M.E.G. Ruiz Santoyo, in literature). A day dependence has been established for other anthropogenic trace gases in urban areas. Carbon monoxide levels, for example, decrease significantly on Sundays (WHO/UNEP, 1992).

\subsection{Statistical analyses—general hydrocarbons}

Interpretation of other hydrocarbon distributions is strongly complicated by spatiotemporal fluctuations in sourcing and removal mechanisms (Table 2). The species derived from gasoline combustion, for example, demonstrate several peaks in concentration that probably reflect underlying traffic patterns (MARI, 1994; Elliott et al.,

Table 3

Comparison of methane concentrations by collection day

\begin{tabular}{lllr}
\hline Time $(\mathrm{h})$ & Day & Day of week & [Methane] $(\mathrm{ppm})$ \\
\hline 13:08 & 18 March & Thursday & 2.22 \\
06:05 & 19 March & Friday & 24.69 \\
13:45 & 19 March & Friday & 1.85 \\
$06: 05$ & 20 March & Saturday & 24.80 \\
14:25 & 20 March & Saturday & 2.01 \\
$06: 30$ & 21 March & Sunday & 2.12 \\
14:55 & 21 March & Sunday & 2.00
\end{tabular}

Data are from a site in Parque Popular, a light industrial area in the northeastern sector of the city (Fig. 1). Businesses located in this area in March 1993 included Altos Hornos de Mexico (smelting), Fertilizantes Mexicanos, Leche Lala, Distribuidora de Gases (Gas Linde), Cannon, Dunlop, Kelvinator, Plastimarx, and Destileria Viejo Vergel, as well as an automobile clutch manufacturer and a cement plant (M.E.G. Ruiz Santoyo, in literature). 
1999). Vehicular activity in the Valley of Mexico forms a virtual square wave rising at 07:00 and falling again at 22:00 $\mathrm{h}$. The meteorological inversion overlaps inputs for several hours in the morning and evening. The dual maxima seen in monitoring data for carbon monoxide were evident for several compounds (Elliott et al., 1997).

The pattern of temporal variation in ethane and propane parallels that of methane (Table 1). Concentrations of both gases are significantly higher from 06:00 to $12: 00 \mathrm{~h}$ than from 12:00 to $18: 00 \mathrm{~h}$ (ANOVA, d.f. $=65 ; P<0.01$ and $P<0.001$, respectively; Duncan and Scheffe multiple range tests, $P<0.05$ ). By contrast with methane, however, afternoon concentrations remain elevated and despite the resumption of general circulation patterns in the afternoon do not drop to background levels (e.g. Table 1). Presumably this is because the gases are reactive on free tropospheric mixing time scales (e.g. Singh and Zimmerman, 1992; Blake et al., 1996a,b,c). They are stable prior to ventilation from the basin, however, and so are useful in our consideration of mass conservation. Since the urban excess is relatively large, winter tropospheric levels could potentially be used for reference (Singh and Zimmerman, 1992); we have subtracted Teotihuacan concentrations. The ethane variance over time is much less heterogeneous than that of methane, suggesting that sources causing spikes in methane concentration are ethane poor.

Reactive hydrocarbons such as the olefins were depleted during periods of high photochemical activity (mid-day). Cloudiness was not a factor during the week long 1993 sampling campaign. Located as it is in the tropics and at high altitude, Mexico City receives high levels of ultraviolet radiation for most of the year. This is one of the reasons often cited for the severity of its oxidant and aerosol pollution problems. Short-lived species were left in the dataset during our factor analyses but are excluded from the chemical mass balance arguments. Average urban excess concentrations for all hydrocarbons can readily be obtained from Table 2.

Table 4

Factor structure matrices for hydrocarbons within Mexico City

\begin{tabular}{|c|c|c|c|c|c|c|}
\hline \multirow[t]{2}{*}{ Hydrocarbon } & \multicolumn{4}{|c|}{ Morning (03:00-12:00h), $N=26$} & \multicolumn{2}{|c|}{ Afternoon $(12: 00-21: 00 \mathrm{~h}), N=34$} \\
\hline & Factor 1 & Factor 2 & Factor 3 & Factor 4 & Factor 1 & Factor 2 \\
\hline 1,3-Butadiene & 0.764 & 0.485 & 0.113 & 0.224 & 0.978 & 0.125 \\
\hline 1-Butene & 0.909 & 0.316 & 0.205 & 0.149 & 0.964 & 0.232 \\
\hline 1-Hexene & 0.721 & 0.431 & 0.375 & -0.034 & 0.904 & 0.073 \\
\hline 3-Me-pentane & 0.121 & 0.368 & 0.904 & -0.006 & 0.744 & 0.478 \\
\hline 2-Me-pentane & 0.195 & 0.414 & 0.872 & 0.489 & 0.847 & 0.425 \\
\hline 1-Pentene & 0.579 & 0.303 & 0.512 & -0.120 & 0.691 & -0.004 \\
\hline Benzene & 0.232 & 0.728 & 0.511 & 0.244 & 0.913 & 0.374 \\
\hline Toluene & -0.031 & 0.164 & 0.953 & 0.047 & 0.713 & 0.644 \\
\hline cis-2-Butene & 0.980 & -0.006 & 0.049 & 0.016 & 0.936 & 0.142 \\
\hline Cyclopentane & 0.316 & 0.581 & 0.741 & -0.024 & 0.889 & 0.396 \\
\hline Ethane & 0.225 & 0.659 & 0.169 & -0.234 & 0.402 & 0.820 \\
\hline Ethene & 0.254 & 0.908 & 0.268 & 0.090 & 0.946 & 0.286 \\
\hline Ethyne & 0.106 & 0.853 & 0.494 & 0.041 & 0.911 & 0.374 \\
\hline$i$-Butane & 0.888 & 0.223 & 0.198 & 0.199 & 0.192 & 0.949 \\
\hline$i$-Butene & 0.854 & 0.438 & 0.180 & 0.117 & 0.979 & 0.137 \\
\hline$i$-Pentane & 0.494 & 0.554 & 0.624 & -0.087 & 0.904 & 0.348 \\
\hline Isoprene & 0.619 & 0.116 & -0.022 & 0.715 & 0.970 & 0.059 \\
\hline Methane & 0.324 & -0.060 & -0.002 & 0.884 & -0.127 & 0.887 \\
\hline Methylcyclopentane & 0.683 & 0.423 & 0.535 & 0.018 & 0.933 & 0.160 \\
\hline$n$-Butane & 0.888 & 0.237 & 0.223 & 0.179 & 0.336 & 0.906 \\
\hline$n$-Hexane & 0.220 & 0.615 & 0.519 & -0.029 & 0.774 & 0.576 \\
\hline n-Heptane & 0.162 & 0.660 & 0.573 & 0.340 & 0.549 & 0.514 \\
\hline$n$-Pentane & 0.408 & 0.560 & 0.695 & -0.070 & 0.888 & 0.329 \\
\hline Propane & 0.892 & 0.163 & 0.159 & 0.245 & -0.027 & 0.971 \\
\hline Propene & 0.619 & 0.690 & 0.266 & 0.192 & 0.970 & 0.194 \\
\hline Propyne & 0.198 & 0.843 & 0.475 & 0.023 & 0.936 & 0.280 \\
\hline trans-2-Butene & 0.979 & -0.097 & -0.029 & 0.106 & 0.965 & 0.086 \\
\hline Eigenvalue & 17.711 & 5.187 & 1.289 & 1.236 & 21.015 & 4.048 \\
\hline Percentage of variance & 63.3 & 18.5 & 4.6 & 4.4 & 75.1 & 14.5 \\
\hline Cumulative explained variance & 63.3 & 81.8 & 86.4 & 90.8 & 75.1 & 89.6 \\
\hline
\end{tabular}

Factor analysis using principal components was conducted on morning and afternoon concentrations separately. Four factors yielded eigenvalues $>1.0$ for the morning samples; two factors were identified from the afternoon samples. A VARIMAX rotation was performed to ensure that factors were orthogonal. Factor loadings are analogous to standardized partial regression coefficients (e.g. the regression for methane $=0.324 F_{1}-0.059 F_{2}-0.002 F_{3}$ $\left.+0.884 F_{4}\right)$ and can be used to identify common emission sources. The largest coefficient is highlighted in bold for each hydrocarbon. Communalities can be calculated by summing the squares of the factor loadings for each hydrocarbon. 
Table 5

Partial signatures for several urban hydrocarbon sources (Blake and Rowland, 1995; Blake et al., 1996a,b,c; Elliott et al., 1999)

\begin{tabular}{lcccccr}
\hline Species & LPG1 & LPG2 & Burns & Auto & Gas & Waste \\
\hline Methane & 0 & 0 & 10 & 10 & 20 & 5000 \\
Ethane & 1 & 1 & 1 & 1 & 1 & 1 \\
Propane & 100 & 100 & 0.25 & 0.3 & 0.1 & - \\
$i$-Butane & 30 & 1 & 0.01 & 0.3 & - & - \\
$n$-Butane & 60 & 0.2 & 0.1 & 2 & 0.05 & - \\
$i$-Pentane & 3 & 0.03 & 0.01 & 1 & - & - \\
$n$-Pentane & 1 & $<0.01$ & 0.03 & 3 & - & - \\
Ethene & 0 & 0 & 1 & 8 & - & - \\
Ethyne & 0 & 0 & 0.5 & 6 & - & - \\
Benzene & 0 & 0 & 0.4 & 4 & - & -
\end{tabular}

LPG1 is a Mexico City average, LPG2 is a Los Angeles average; burns includes incineration processes and biomass combustion; auto is from actual vehicle samples obtained during the sampling campaign in 1993; gas is natural gas leakage; waste is an average for sewage and landfill emissions. Input types are organized by increasing $\mathrm{CH}_{4} / \mathrm{C}_{2} \mathrm{H}_{6}$ ratio.

\subsection{Factor analysis using principal components}

Analysis of the morning air samples within the Metropolitan area yielded 4 factors with eigenvalues $>1.0$; together these explained $90.8 \%$ of the variance (Table 4 ). The communalities for most were high (more than $\sim 0.9$ ), indicating that most variance was explained by the four components. A notable exception was ethane. The computed communality was 0.569 , suggesting that only $32 \%$ of the variation in ethane concentration was explained by the factor loadings.

By examining the loadings of each hydrocarbon on the four principal components (e.g. Table 4; Fig. 3a), and comparing them to urban source fingerprints (Table 5), we can identify the most likely common causal agents. Factor 1 reflects mainly the widespread consumption of liquefied petroleum gas (Blake and Rowland, 1995). Species that loaded strongly on this component (all $>0.84$, representing $>70 \%$ of the variation in these tracers; Tables 2 and 4) include 1-butene, cis-2-butene, $i$-butane, iso-butene, $n$-butane, propane and trans-2-butene. These are prominent components of commercially available Mexican LPG (Blake and Rowland, 1995). Factor 2 appears to relate to fuel combustion processes. Gases loading strongly (>0.84) are ethene, ethyne, and propyne; weaker loadings are seen for benzene, ethane, $n-\mathrm{C}_{7} \mathrm{H}_{16}$ and propene $(\sim 0.65-0.73)$. The $\mathrm{C}_{2}$ species are key tracers for vehicular activity (Singh and Zimmerman, 1992; Table 5). Incineration may contribute as well. Several emission sources may be mixed in factor 3 . The only hydrocarbon loading strongly on factor 4 is methane (0.88), although isoprene ( 0.71 , or $\sim 50 \%$ of its variation) is represented to a lesser degree (Fig. 3a). Isoprene is biogenically derived from plants and is unlikely to have a common release mechanism with methane. Thus, we interpret this component as representing hydrocarbons with a source not expressed by factors $1-3$. Our results suggest that methane is mostly derived from "pure" sources; in Mexico City, the only likely candidates are landfills and sewers. Were other potential emitters involved (e.g. natural gas usage, combustion, biomass burning), we would expect to see additional tracers loading on factor 4 .

The afternoon samples yielded two factors with eigenvalues >1.0; together these explained $89.5 \%$ of the variance (Table 4; Fig. 3b). Again, the communalities were high (more than $\sim 0.9$ ), with the exception of 1-pentene and $n-\mathrm{C}_{7} \mathrm{H}_{16}$ (0.48 and 0.57 , respectively). For stable molecules, the afternoon urban excess reflects relative overall emissions, because ventilation is the primary loss mode and mixing rates have maximized. The $n$-pentane, ethene and ethyne are attributable to traffic, with perhaps $5 \mathrm{ppb}$ ethane and $50 \mathrm{ppb}$ methane attendant (Table 5). We assign factor 1 to the combination of automobile emissions and photochemical effects (short-lived NMHC). Note that the vehicle fleet may contribute one quarter of the integrated $\mathrm{CH}_{4}$ input (50 of $200 \mathrm{ppb}$; Table 2). Methane, ethane, $i$-butane, $n$-butane and propane all loaded strongly on component 2 ; we interpret this as a combination of natural gas/LPG usage and other methane rich inputs (Table 5). To determine whether the methane was correlated to LPG/natural gas emissions or attributable to another source, we reran the principal component analysis on the afternoon data, restricting the variables to those that loaded most strongly on factor $2(>0.7$; Table 4). This analysis yielded two factors that clearly separated methane from all other hydrocarbons. Again, methane loaded alone on factor 2, while all other tracers were found associated with factor 1 . We interpret this as reinforcing the source fingerprints identified in the morning analysis.

\subsection{Calculation of integrated methane flux}

The tropospheric background concentration for central Mexico, we take to be the mean of the Teotihuacan data, $1.783 \mathrm{ppm}$ (Table 2). The binned data from 15:00 to 18:00 $\mathrm{h}$ are likely to reflect the most complete atmospheric mixing (Elliott et al., 1997). The mean of the urban values for this time period are $1.9417 \mathrm{ppm}$, leading to an urban excess of $\sim 150 \mathrm{ppb}$. Note that binned values for other time periods (prior to full mixing of the atmosphere; Table 1) lead to vastly different estimations of the urban excess. Understanding of the underlying atmospheric circulation patterns is crucial to our computations. Assuming a rectangular geometry, we estimate that the Valley of Mexico contains $\sim 1.0 \times 10^{38}$ molecules $(50 \mathrm{~km} \times 50 \mathrm{~km} \times 2 \mathrm{~km}$ at local pressure). Air resides in the basin $\sim 0.75$ day in models of winter flow (Fast and Zhong, 1998). Earlier one-dimensional modeling has estimated the vertical fall off to be a factor of 3 to $2 \mathrm{~km}$ for stable species sourced from the city (Elliott et al., 1997). The surface concentration may be adjusted by $2 / 3$ to account for the drop. Thus, we estimate that $\sim 1.33 \times 10^{31}$ molecules per day ( $\sim 360$ metric tons per day) of methane must enter the basin to compensate for outflow. Morning build-up (relative to $1.9 \mathrm{ppm}$ for the latest evening data) is $1.4 \mathrm{ppm}$ for the $03: 00-06: 00 \mathrm{~h} \mathrm{bin}$, and $6.0 \mathrm{ppm}$ for the 06:00-09:00 $\mathrm{h}$ bin (Table 1). The nocturnal inver- 
(a)
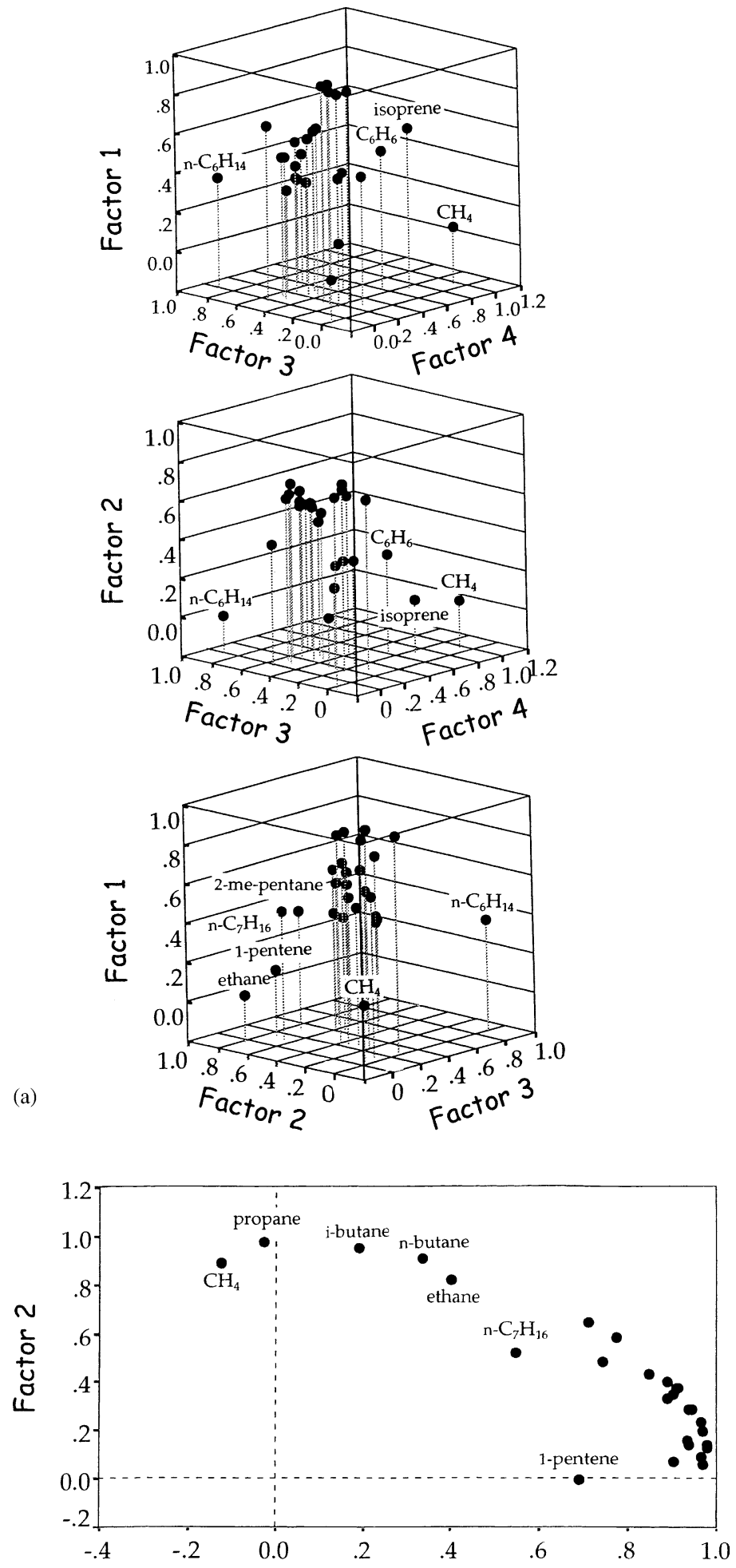

(b)

Factor 1

Fig. 3. Rotated factor loadings. (a) Morning (06:00-12:00 h). All combinations of the three significant factors are shown. (b) Afternoon (12:00-21:00 h). There were only two significant factors. See Table 4 for explanation of loadings. 
sion is established at an average of 22:00 h (MARI, 1994; Elliott et al., 1997) and at heights varying from 100 to $200 \mathrm{~m}$ (MARI, 1994; Vidal and Raga, 1998). Here, we use a median value of $150 \mathrm{~m}$. Approximately $7.5 \times 10^{36}$ molecules lie below the inversion within the valley, with about half the basin covered by urban areas. Little horizontal mixing occurs until the afternoon, thus, methane molecules are being added to the $\sim 3.75 \times 10^{36}$ molecules contained within the three-dimensional city atmospheric space. Build-up to $04: 30 \mathrm{~h}$ is $8.047 \times 10^{29}$ molecules $/ \mathrm{h}$. The early-morning data translate to $\sim 2.0 \times 10^{31}$ molecules per day $(\sim 515$ metric tons per day). The values for the build-up to $07: 30 \mathrm{~h}$ are $2.38 \times 10^{30}$ molecules/h and $5.7 \times 10^{31}$ molecules per day ( $\sim 1525$ metric tons per day). Since the variance increases as mid-day is approached, it is likely that data from earlier in the morning are more representative. The independent approaches indicate an injection of $\sim 515$ metric tons of methane per day from the city into the Valley of Mexico.

The basin methane cycle can be placed in a global perspective by normalizing to the urban population $(\sim 17 \times$ $10^{6}$ inhabitants in 1993). Mexico City releases a total of 0.011 metric tons $\mathrm{CH}_{4}$ per year per person to the regional troposphere from all sources [ $\sim 515$ metric tons per day $\times$ 365 days $) / 17 \times 10^{6}$ persons]. Our factor analysis suggests that the major inputs are landfills, sewage and vehicles (e.g. Tables 4 and 5). The flux thus constitutes an upper limit to human associated anaerobic production. Globally, total per capita anthropogenic production is $\sim 0.068$ metric tons $\mathrm{CH}_{4}$ per year per person (e.g. for $1995, \sim 535 \times 10^{12} \mathrm{~g}$ per year $/ 5.5 \times 10^{9}$ persons; Cicerone and Oremland, 1988). This figure includes rice paddies, enteric fermentation, animal waste, coal combustion and coal mines, none of which are likely inputs within the Valley of Mexico. Eliminating these sources yields a figure of $\sim 0.029$ metric tons $\mathrm{CH}_{4}$ per year per person, which is still almost double our estimate of the 0.011 metric tons $\mathrm{CH}_{4}$ per year per person produced in Mexico City. In fact, our figure is close to the global per capita average emissions from landfills alone $(\sim 0.01$ metric tons per year, or a total of $\sim 60 \times 10^{12} \mathrm{~g}$ per year; Houghton et al., 1996). Even given uncertainties in global estimates (e.g. the range for methane from landfills is from $20 \times 10^{12}$ to $70 \times 10^{12} \mathrm{~g}$ per year; Bogner and Spokas, 1993; Bogner et al., 1997), our comparison suggests that Mexico City may be releasing less methane than expected on a per capita basis.

\subsection{Calculation of leak rates}

Mexico City consumes approximately $500 \mathrm{pJ}$ of energy per year of which $20 \%$ derives from natural gas and another $20 \%$ from LPG (Villarreal et al., 1996). Methane usage is $5000 \mathrm{t}$ per day (carbon content from OTA, 1991). Given that the natural gas signature plays only a minor role in source distributions, we estimate leakage to be on the order of $1 \%$. The efficiency may be attributed in part to the government decision to restrict gas consumption to the industrial sector. Losses are comparable to those estimated for the global gas production life cycle (Muller, 1992). At the propane/butane carbon content (OTA, 1991), LPG combustion comes to $5400 \mathrm{t}$ per day. Half of the Mexico LPG is butane by moles (Elliott et al., 1999); propane combustion is then $2300 \mathrm{t}$ per day. The bottom up and top down basin budget manipulations give $200 \mathrm{t}$ per day as a city-wide propane flux. Losses were on the order of 5-10\% during the sampling period in 1993. LPG services mainly the residential areas of the city. The Mexican Petroleum Institute has identified pilot lights in cooking devices as one of the major sources of leaks (M. Ruiz, personal communication). Residential applications of the commercial petroleum gases are clearly a potential weak point within energy infrastructures of the developing megacities.

\section{Discussion}

The Valley of Mexico has been called the 'heart of the nation' not only because $\sim 30 \%$ of the population is located there, but also because it largely controls the economy, financial system, communication networks and government of the country (Nord, 1996; Pick and Butler, 1997). Its importance as a primate city is of long standing; estimates of preconquest population are as high as 500,000 inhabitants (Nord, 1996). Although warfare and disease introduced by European conquistadors decimated the city, it remained an important focal point for the nation. Population growth accelerated during the Revolutionary War, as ruralites fled the conflict and sought refuge in the city. Continued immigration and high birth rates since that time have lead to the creation of the modern megacity.

The rapid urbanization in the Valley of Mexico has transformed the entire environment. Extensive wetlands and lakes once dominated the basin. By the 19th century, however, flood control, increasing water demands, and the need for land for construction, had drastically reduced the extent of wetlands (Nord, 1996; Pick and Butler, 1997). Thus, early on, human settlement drastically impacted the local methane budget (e.g. Subak, 1994; Etheridge et al., 1998). Some swamps still exist today in the area around Lake Texcoco. These are fairly limited and are located well outside our sampling area. The land surfaces within the valley also have been extensively reshaped, leading to soil erosion and loss of woodlands and native vegetation. Extensive squatter settlements have sprung up on the periphery of the downtown area; most are without adequate water, sewage, energy or other utilities (WHO/UNEP, 1994; Pick and Butler, 1997). The lack of infrastructure, coupled with rapid population growth, has led to widespread environmental degradation.

A number of studies have examined the environmental challenges Mexico City faces, much of them focused on the visible and charismatic problem of air pollution (e.g. Garfias and Gonzalez, 1992; Nickerson et al., 1992; Ruiz-Suarez et al., 1993; Blake and Rowland, 1995; Streit and Guzman, 1996; Riveros et al., 1995; Bossert, 1997; Elliott et al., 1997; 


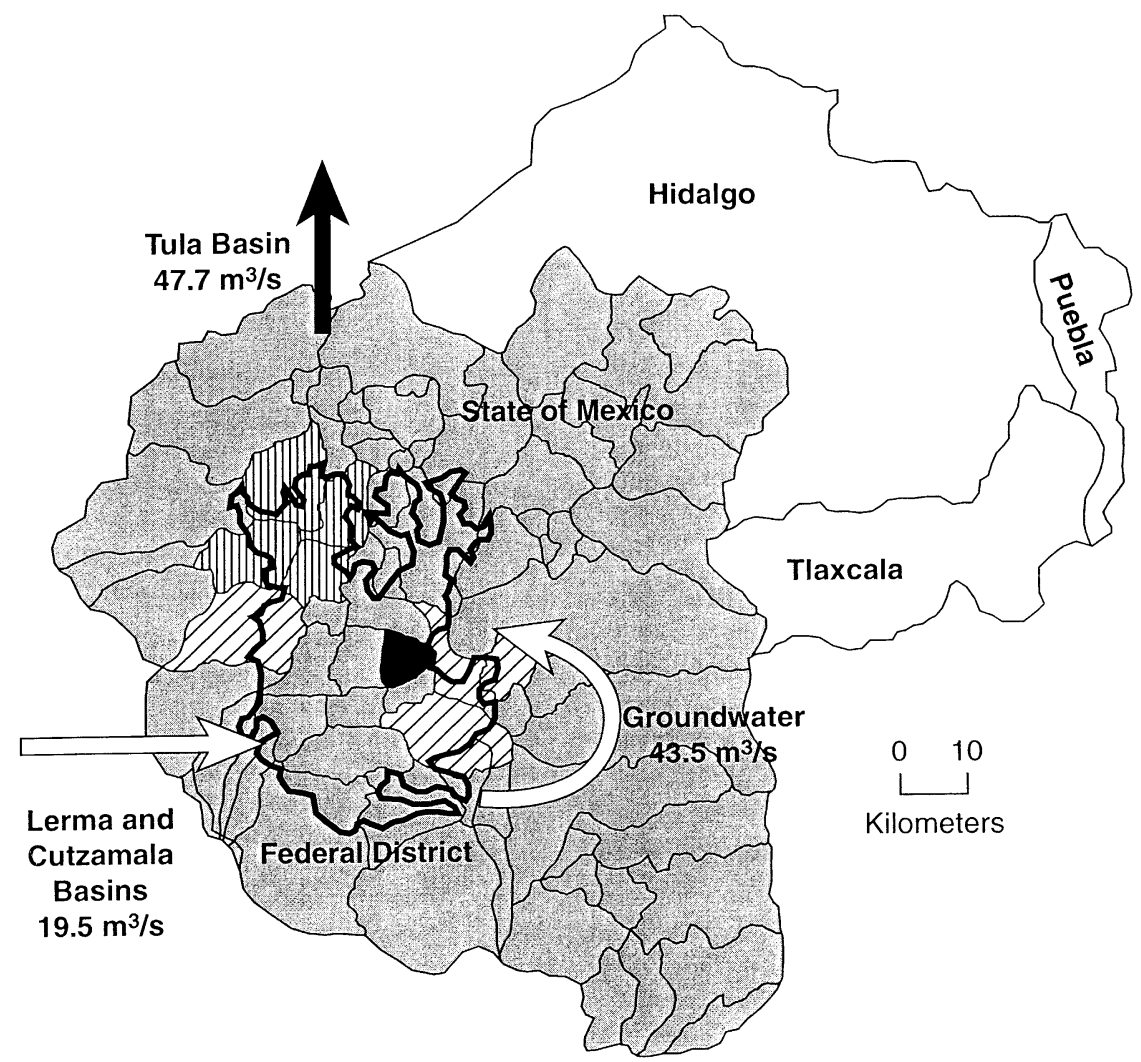

Areas containing few ( $\leq 4 \mathrm{ha}$ ) landfills

IIII Areas containing low density (5-9 ha) of landfills

$\square$ Areas containing moderate density (17-40 ha) of landfills

Areas containing high density (>104 ha) of landfills

Fig. 4. Location of landfills and path of water and sewage within the Mexico City metropolitan area. Figure is redrawn from the Butler/Pick Mexico Database (Pick and Butler, 1997). Open arrows indicate water inputs into the basin; the large filled arrow indicates the open sewage channel (the "Grand Canal') by which most wastewater exists.

Vidal and Raga, 1998). We have focused here on methane because of its importance as a greenhouse gas forcing terrestrial climate. Our analysis, based on rural and urban measurements (Tables 1 and 2; Fig. 2), suggests the Valley of Mexico inputs $\sim 515$ metric tons of methane per day ( $\sim 187,975$ metric tons per year) into the troposphere. Earlier speculation (e.g. Elliott et al., 1997, 1999) postulated that a leaky infrastructure could account for a substantial portion of the methane, similar to the problems found with LPG usage (Blake and Rowland, 1995). Earthquake safety concerns, however, have restricted residential and industrial usage of natural gas. Consequently, the gas infrastructure is limited in scope and leak rates are comparable to other urban areas (Shorter et al., 1996; Harriss, 1994; Houghton et al., 1996). If the use of natural gas were widespread, we might well expect both the fractional and absolute leak rates to increase; maintaining a large network would be difficult under the tight fiscal restrictions faced by Mexico and other emerging megacities (Chen and Heligman, 1994; Nord, 1996).
Given the increasing switch towards cleaner fuel sources in developing areas (WHO/UNEP, 1992, 1994), it is clear that maintenance, regulation and enforcement of industries will be essential to keep leakage at acceptable levels. It has been estimated, for example, that leak rates during the transportation, distribution and usage of natural gas must be less than 2.4-2.9\% to get reduction in climate forcing when switching from oil to gas, and less than $4.3-5.7 \%$ to be less harmful than coal (Lelieveld et al., 1993).

We found significant spatial and temporal variation in methane concentrations within the Valley of Mexico (Table 1; Fig. 2). Several conclusions can be drawn. First, our results underscore the importance of understanding the underlying air circulation patterns and meteorology when measurements are interpreted. Had our calculation of methane 'urban excess' been based on morning values, for example, we would have estimated fluxes an order of magnitude greater than those obtained in the afternoon. Second, the high variability in concentrations found prior to 
atmospheric mixing in the early-afternoon suggest at least some point sources for methane emissions. That some of these are from businesses is evidenced by their locations within the industrial sector of the city, and by the reduced concentrations measured on Sundays (e.g. Figs. 1 and 4; Table 3). Nevertheless, because of Mexico City's location in a seismically active zone, little natural gas is actually used by the residential and industrial sector (Blake and Rowland, 1995; Elliott et al., 1999).

Despite the presence of some point sources, principal component analysis suggested that methane was derived in large part from pure sources (e.g. Tables 4 and 5; Fig. 3). Such potential inputs include swamps, landfills, sewage, and losses associated with the transportation and distribution system. We have argued that leakage is unlikely to be the primary cause; the $\mathrm{C}_{1} / \mathrm{C}_{2}$ ratios observed during the morning are not consistent with substantial natural gas leakage (e.g. Table 5). Swamps are an important source of biogenic methane, but the limited wetlands remaining probably only contribute in a modest way to the high urban background levels. Our factor analysis implicated landfills and sewage as the most important contributors (Table 5). Studies in Los Angeles and Boston have indicated that even in developed countries, landfills and sewage are major sources of methane inputs (Hogan, 1993; Houghton et al., 1996). We expected that the amount of methane produced by landfills and sewage would be much higher in Mexico City than other urban areas, not only because of its much large population, but because much of it is untreated. Some 15,046t per day of trash was generated in Mexico City in 1992 (Pick and Butler, 1997). Unlike cities in more developed countries, however, a substantial amount ( $\gg 25 \%$ ) ended-up in illegal uncovered landfills at the southern and eastern periphery of the city (Pick and Butler, 1997; Fig. 4). Wastewater is disposed of through an open sewage channel called the 'Grand Canal', and by a deep transmission system called the 'Emisor Central' built in 1960 (Fig. 4). Only a small portion of the sewage is actually serviced by these two systems, however. A recent study reported that only $44.3 \%$ of the area within the Federal District and $27.3 \%$ of that within the 17 Municipios in the metropolis are served by water and wastewater disposal systems (Pick and Butler, 1997). The remaining effluent is released into the local environment and is known as the 'aguas negras', or black waters. The inadequate sewage infrastructure was further compromised by the 1985 earthquake, which damaged portions of the system. Despite all this, our per capita calculations suggest that anthropogenic production of methane in Mexico City is less than the global average. We estimate that 0.011 metric tons $\mathrm{CH}_{4}$ per year per person is released in the atmosphere from all sources. This is on the order of the global per capita average for landfills alone -0.002 to 0.01 metric tons $\mathrm{CH}_{4}$ per year per person, with the latter value more appropriate because of the lack of highly controlled landfill sites within Mexico City (Bogner and Spokas, 1993; Houghton et al., 1996; Bogner et al., 1997). The result is an apparent paradox because of the well documented pollution problems and poorly and/or marginally treated effluent and waste (e.g. WHO/UNEP, 1994). One possibility is that as poor as the urban sanitation system is, it still outperforms that of other rural and less urbanized counterparts in other regions of the world. Another intriguing possibility is that the methane burden scales nonlinearly with city size or level of development. If this is indeed the case, increased urbanization could actually reduce climate forcing in the short-term by anthropogenic greenhouse gases. Given the large uncertainties in global estimates, more study is clearly called for.

The exclusion of methane from the Kyoto mandated emissions agreements and trading may have substantial impacts on our ability to reduce anthropogenic climate forcing. Although found in much lower concentration in the atmosphere than carbon dioxide, its far greater potency as a greenhouse gas means that its contribution to climate forcing is 35-50\% that of carbon dioxide (Houghton et al., 1992, 1996; Lelieveld and Crutzen, 1992; Lelieveld et al., 1993, 1998). Human activities are now estimated to be responsible for $\sim 70 \%$ of global methane emissions (Houghton et al., 1996; Lelieveld et al., 1998), thus, methane reduction should be a major objective in greenhouse mitigation strategies. The United States Climate Change Action Plan announced by the Clinton Administration in 1993 identified methane reduction as a major objective (Clinton and Gore, 1993). However, new leadership in the US executive branch has increasingly turned away from treaties while emphasizing large-scale technological solutions to the climate change dilemma. Thus, how effective the Bush Administration will ultimately be in mitigating or reducing anthropogenic environmental impacts remains unclear. Finally, we note that the majority of the many studies investigating methane production and/or budgets have focused on highly developed countries (e.g. Crill, 1991; Bogner and Spokas, 1993; Frolking and Crill, 1994; Castro et al., 1995; Mosier et al., 1996). Further investigations of the increasing role developing countries play in global atmospheric budgets is essential. Studies are especially needed that investigate the effects of urbanization on methane production. Moreover, our results also highlight the importance of detailed examination of spatiotemporal variation within the context of local meteorology and climate.

\section{Acknowledgements}

We thank M.E.G. Ruiz Santoyo for providing us with unpublished data on natural gas leakage and geopolitical information.

\section{References}

Aldape, F., Flores, M.J., Diaz, R.V., Morales, J.R., Cahill, T.A., Saravia, L., 1991. Seasonal study of the composition of the atmospheric aerosols in Mexico City. Int. J. PIXE 1, 355-371. 
Aldape, F., Flores, M.J., Diaz, R.V., Crumpton, D., 1993. Temporal variations in elemental concentrations of atmospheric aerosols in Mexico City. Nucl. Instrum. Methods Phys. Res. 75 (Section B), 304307.

Blake, D.R., Rowland, F.S., 1995. Urban leakage of liquefied petroleum gas and its impact on Mexico City air quality. Science 269, 953-956.

Blake, D.R., Woo, V.H., Tyler, S.C., Rowland, F.S., 1984. Methane concentrations and source strengths in urban locations. Geophys. Res. Lett. $11,1211-1214$.

Blake, D.R., Hurst, D.F., Tyrrel, W., Smith, W., Whipple, W.J., Chen, T.Y., Blake, N.J., Rowland, F.S., 1992. Summertime measurements of selected nonmethane hydrocarbons in the arctic and subarctic during the 1988 Arctic Boundary Layer Expedition. J. Geophys. Res. 97, 16559-16588.

Blake, D.R., Blake, N.J., Smith, T.W., Wingenter, O.W., Rowland, F.S., 1996a. Nonmethane hydrocarbon and halocarbon distributions during Atlantic Stratocumulus Transition Experiment June 1992. J. Geophys. Res. 101, 4501-4514.

Blake, D.R., Chen, T.Y., Smith, T.W., Wang, C.J.L., Wingenter, O.W., Blake, N.J., Rowland, F.S., 1996b. Three-dimensional distribution of nonmethane hydrocarbons and halocarbons over the northwestern Pacific during the 1991 Pacific Exploratory Mission (PEM West A). J. Geophys. Res. 101, 1763-1778.

Blake, N.J., Blake, D.R., Sive, B.C., Chen, T.Y., Rowland, F.S., 1996c. Biomass burning emissions and vertical distribution of atmospheric methyl halides and other reduced carbon gases in the south Atlantic region. J. Geophys. Res. 101, 24151-24164.

Bogner, J., Spokas, K., 1993. Landfill methane: rates, fates, and role in global carbon cycle. Chemosphere 26, 369-386.

Bogner, J., Meadows, M., Czepiel, P., 1997. Fluxes of methane between landfills and the atmosphere: natural and engineered controls. Soil Use Manage. 13, 268-277.

Bossert, J.E., 1997. An investigation of flow regimes affecting the Mexico City region. J. Appl. Meteorol. 36, 119-140.

Castro, M.S., Steudler, P.A., Melillo, J.M., Aber, J.D., Bowden, R.D., 1995. Factors controlling atmospheric methane consumption by temperate forest soils. Global Biogeochem. Cycles 9, 1-10.

Chen, N.Y., Heligman, L., 1994. Growth of the world's megalopolises. In: Fuchs, R.J., Brennan, E., Chamie, J., Lo, F., Uitto, J.I. (Eds.), Mega-City Growth and the Future. United Nations University Press, Tokyo.

Cicerone, R.J., Oremland, R.S., 1988. Biogeochemical aspects of atmospheric methane. Global Biogeochem. Cycles 2, 299-327.

Clinton, W.J., Gore Jr., A., 1993. The Climate Change Action Plan. Washington, DC.

Crill, R.M., 1991. Seasonal patterns of methane uptake and carbon dioxide release by a temperate woodland soil. Global Biogeochem. Cycles 5, 319-334.

Dlugokencky, E.J., Steele, L.P., Lang, P.M., Masarie, K.A., 1994. The growth-rate and distribution of atmospheric methane. J. Geophys. Res.: Atmos. 99, 17021-17043.

Elliott, S., Blake, D.R., Rowland, F.S., Lu, R., Brown, M.J., Williams, M.D., Russell, A.G., Bossert, J.E., Streit, G.E., Santoyo, M.R., Guzman, F., Porch, W.M., McNair, L.A., Keyantash, J., Kao, C.Y.J., Turco, R.P., Eichinger, W.E., 1997. Ventilation of liquefied petroleum gas components from the Valley of Mexico. J. Geophys. Res.: Atmos. 102, 211997-212007.

Elliott, S., Blake, D.R., Bossert, J.E., Chow, J., Colina, J.A., Dubey, M., Duce, R.A., Edgerton, S., Gaffney, J., Gupta, M., Guzman, F., Matson, P.A., McNair, L.A., Ortiz, E., Riley, W., Rowland, F.S., Ruiz, M.E., Russell, A.G., Smith, F.A., Sosa, G., Streit, G., Watson, J., 1999. Mexico City and the biogeochemistry of global urbanization. Los Alamos Report LA-13516-MS, Los Alamos National Laboratory.

Etheridge, D.M., Steele, L.P., Francey, R.J., Langenfelds, R.L., 1998. Atmospheric methane between 1000 A.D. and present: evidence of anthropogenic emissions and climate variability. J. Geophys. Res. 103, 15979-15993.
Fast, J., Zhong, S., 1998. Meteorological factors associated with inhomogeneous ozone concentrations within the Mexico City basin. J. Geophys. Res. 103, 18927-18946.

Frolking, S., Crill, P., 1994. Climate controls on temporal variability of methane flux from a poor fen in Southeastern New Hampshire, measurement and modeling. Global Biogeochem. Cycles 8, 385-397.

Garfias, J., Gonzalez, R., 1992. Air quality in Mexico City. In: Dunnette, D.A., O'Brien, R.J. (Eds.), The Science of Global Change: The Impact of Human Activities on the Environment. American Chemical Society, Washington, DC

Harriss, R., 1994. Reducing urban sources of methane: an experiment in industrial ecology. In: Socolow, R., Andrews, C., Berkhout, F., Thomas, V. (Eds.), Industrial Ecology and Global Change. Cambridge University Press, Cambridge, MA.

Henry, R.C., Hidy, G.M., 1979. Multivariate analysis of particulate sulfate and other air quality variables by principal components. Part I. Annual data from Los Angeles and New York. Atmos. Environ. 13, 1581-1586.

Henry, R.C., Hidy, G.M., 1981. Multivariate analysis of particulate sulfate and other air quality variables by principal components. II. Salt Lake City, Utah and St. Louis, Missouri. Atmos. Environ. 16, 929-943.

Hogan, K.B. (Ed.), 1993. Anthropogenic methane emissions in the United States: estimates for 1990. United States Environmental Protection Agency, Office of Air and Radiation Report Number 430-R-93-003, Washington, DC.

Hopke, P.K., 1981. The application of factor analysis to urban aerosol source resolution. In: Macias, E.S., Hopke, P.K. (Eds.), Atmospheric Aerosol: Source/Air Quality Relationships. Symposium Series No. 167, American Chemical Society, Washington, DC.

Hopke, P.K., 1985. Receptor Modeling in Environmental Chemistry. Wiley, New York.

Hopke, P.K., Severin, K.G., Chang, S.N., 1983. Application and verification studies of target transformation factor analysis as an aerosol receptor model. In: Dattner, S.L., Hopke, P.K. (Eds.), Receptor Models Applied to Contemporary Pollution Problems. Air Pollution Control Association, Pittsburgh, PA.

Houghton, J.T., Callander, B.A., Varney, S.K., 1992. Climate Change 1992: The Supplementary Report to the IPCC Scientific Assessment. Cambridge University Press, New York.

Houghton, J.T., Meira Filho, L.G., Callander, B.A., Harris, N., Kattenberg, A., Maskell, K., 1996. Climate Change 1995: The Science of Climate Change. Cambridge University Press, New York.

Lelieveld, J., Crutzen, P.J., 1992. Indirect chemical effects of methane on climate warming. Nature 355, 339-342.

Lelieveld, J., Crutzen, P.J., Bruhl, C., 1993. Climate effects of atmospheric methane. Chemosphere 26, 739-768.

Lelieveld, J., Crutzen, P.J., Dentener, F.J., 1998. Changing concentration, lifetime and climate forcing of atmospheric methane. Tellus Ser. B: Chem. Phys. Meteorol. 50, 128-150.

Mexico City Air Quality Research Initiative (MARI), 1994. The Mexico City air quality research initiative. Los Alamos National Lab Report LA-12699, Los Alamos.

Miranda, J., Cahill, T.A., J, R., Aldape, F., Flores, M.J., Diaz, R.V., 1994 Determination of elemental concentrations in atmospheric aerosols in Mexico City using proton induced X-ray emission, proton elastic scattering, and laser absorption. Atmos. Environ. 28, 2299-2306.

Mosier, A.R., Parton, W.J., Valentine, D.W., Ojima, D.S., Schimel, D.S., Delgado, J.A., 1996. $\mathrm{CH}_{4}$ and $\mathrm{N}_{2} \mathrm{O}$ fluxes in the Colorado shortgrass steppe. 1. Impact of landscape and nitrogen addition. Global Biogeochem. Cycles 10, 387-399.

Muller, J.F., 1992. Geographic distribution and seasonal variation of surface emissions and deposition velocities of atmospheric trace gases. J. Geophys. Res. 97, 3787-3804.

Nickerson, E.C., Sosa, G., Hochstein, H., McCaslin, P., Luke, W., Schanot, A., 1992. Project Aguila: in situ measurements of Mexico City air pollution by a research aircraft. Atmos. Environ. 26B, 445.

Nord, B., 1996. Mexico City's Alternative Futures. University Press of America, Lanham. 
Norusis, M.J., 1986. SPSS/PC+ Advanced Statistics. SPSS Incorporated, Chicago.

Office of Technology Assessment of the United States Congress (OTA), 1991. Changing by Degrees: Steps to Reduce Greenhouse Gases. Cutter Information Corporation, Arlington.

Pick, J.B., Butler, E.W., 1997. Mexico Megacity. Westview Press, Boulder, CO.

Riveros, H.G., Tejeda, J., Ortiz, L., Julian-Sanchez, A., Riveros-Rosas, H., 1995. Hydrocarbons and carbon monoxide in the atmosphere of Mexico City. J. Air Waste Manage. 45, 973-980.

Ruiz-Suarez, J.C., Ruiz-Suarez, L.G., Gay, C., Castro, T., Montero, M., Eidels-Duvoboi, S., Muhlia, A., 1993. Photolytic rates for $\mathrm{NO}_{2}, \mathrm{O}_{3}$ and HCHO in the atmosphere of Mexico City. Atmos. Environ. 27A, 427.

Shorter, J.H., McManus, J.B., Kolb, C.E., Allwine, E.J., Lamb, B.K., Mosher, B.W., Harriss, R.C., Partchatka, U., Fischer, H., Harris, G.W., Crutzen, P.J., Karback, H., 1996. Methane emission measurements in urban areas in eastern Germany. J. Atmos. Chem. 24, 121-140.

Singh, H.B., Zimmerman, P.B., 1992. Atmospheric distribution and sources of nonmethane hydrocarbons. In: Nriagu, J.O. (Ed.), Gaseous Pollutants: Characterization and Cycling. Wiley, New York, NY.

Streit, G.E., Guzman, F., 1996. Mexico City air quality: progress of an international collaborative project to define air quality management options. Atmos. Environ. 30, 723-733.

Subak, S., 1994. Methane from the house-of-Tudor and the Ming-Dynasty: anthropogenic emissions in the 16th century. Chemosphere 29, 843854.

United Nations (UN), 1989. Prospects of World Urbanization 1988. Population Studies No. 112, New York.

United Nations Centre for Human Settlements (UNCHS), 1986. Global Report on Human Settlements 1986. United Nations, New York.

Vidal, H.P., Raga, G.B., 1998. On the vertical distribution of pollutants in Mexico City. Atmosfera 11, 95-108.

Villarreal, O.E., Quiroz, C.C., Lillo, J.C., Ramierz, J.R., 1996. Programa para mejorar la calidad del aire en el Valle de Mexico. Departamento del Distrito Federal, Mexico City, D.F.

Watson, J.G., 1983. Overview of receptor model principles. In: Dattner, S.L., Hopke, P.K. (Eds.), Receptor Models Applied to Contemporary Pollution Problems. Air Pollution Control Association, Pittsburgh, PA.

World Health Organization/United Nations Environment Programme (WHO/UNEP), 1992. Urban Air Pollution in Megacities of the World. World Health Organization, United Nations Environment Programme, Blackwell, Oxford.
World Health Organization/United Nations Environment Programme (WHO/UNEP), 1994. Air Pollution in the World's Megacities. Environment 36, 4-37.

Felisa A. Smith is a research associate professor in the Department of Biology at the University of New Mexico. Her interests in Urban Ecology Center around the scaling of various inputs and outputs (particularly energy usage) with city size. She is also keenly interested in the response of organisms to past and present climate change. Currently she is using woodrat paleomiddens to investigate the impact of climate change on the ecology and evolution of mammals over the late-Quaternary.

Scott Elliott is a biogeochemistry researcher in the Earth and Environmental Sciences Division at Los Alamos National Laboratory. His group studies several global scale geocycling issues including the role of urbanization in driving regional ozone/aerosol distribution changes, and links from air pollution to ecodynamics on land and in the sea. Elliott and company also develop fine resolution global simulations of elemental processing by marine ecosystems, in the Los Alamos eddy resolving ocean circulation models.

Donald R. Blake is an analytical atmospheric chemist at the University of California, Irvine. His group performs gas chromatography on air samples from around the world, in order to determine tropospheric trace hydrocarbon concentrations and distributions. Blake and colleagues participate in multiple ground based and aircraft atmospheric chemistry measurement campaigns per year. Their results have helped to elucidate global atmospheric methane increases and the contribution of megacities to regional photooxidation processes.

F. Sherwood Rowland began his career in the late-1950s and early-1960s as a hot atom chemist. He and his group performed intermittent atmospheric and environmental studies during this period. In the mid-1970s while working with then post-doctoral fellow Mario Molina, Rowland discovered the potential for chlorine originating from anthropogenic halocarbons to enter the stratosphere and catalyze massive, world-wide ozone depletion. His group rapidly evolved into a general atmospheric trace gas measurements facility. Rowland was awarded the Nobel Prize in chemistry in 1995 for his pioneering work on ozone. 